\title{
Paulina Filip
}

Uniwersytet Rzeszowski

\section{Aktywność ekonomiczna przedsiębiorstw małej i średniej skali w Polsce}

Doświadczenie krajów o rozwiniętej gospodarce rynkowej wykazuje, iż rozwój sektora małych i średnich przedsiębiorstw jest konieczny w celu sprawnego funkcjonowania całej gospodarki i mechanizmów w niej zachodzących. Jego stymulujące oddziaływanie na gospodarkę wyraża się w dynamicznym reagowaniu na zmiany w otoczeniu, bowiem to mniejsze przedsiębiorstwa są bardziej elastyczne względem nowych potrzeb oraz zmieniających się preferencji klientów. Ich liczba oraz potencjał jest jedną z ważnych miar oceny wzrostu gospodarczego kraju. Rozwój badanego sektora jest związany z uwarunkowaniami wynikającymi ze stanu rozwoju gospodarki narodowej, jej struktury, kondycji ekonomicznej, możliwości finansowych państwa i samorządów terytorialnych oraz polityki gospodarczej. Działając w tym sektorze należy poznać wszelkie uwarunkowania, aby eliminować ich negatywny wpływ i aby móc prowadzić aktywną politykę ekonomiczną umożliwiającą likwidowanie tych barier. Zwiększenie udziału małego i średniego biznesu w Polsce może stać się zarówno motorem wzrostu gospodarczego, jak i istotnym czynnikiem zbliżającym nas do struktury gospodarczej rozwiniętych państw Unii Europejskiej.

W Polsce transformacja ustrojowa stworzyła warunki sprzyjające szybkiemu rozwojowi sektora małej i średniej przedsiębiorczości. Aktualnie małe i średnie przedsiębiorstwa stanowią w Polsce grupę najliczniejszą i pełnią ważną funkcję w gospodarce, wpływając na tak istotne kwestie, jak: wzrost gospodarczy, konkurencyjność, zmiany struktury gospodarczej i wielkość bezrobocia.

Analizując dotychczasowy rozwój przedsiębiorczości w Polsce, można wyróżnić kilka okresów, takich jak:

- wypełnianie luki rynkowej (1989-1992),

- dynamiczny wzrost liczby małych i średnich przedsiębiorstw (1992-1994),

- kształtowanie branż i różnicowanie wewnętrzne (1995-1998),

- wzrost rynkowo-branżowej konkurencji wewnętrznej (1999-2004),

- funkcjonowanie na jednolitym rynku europejskim (od 2004 r.).

Celem niniejszego opracowania jest ocena rozwoju małych i średnich przedsiębiorstw w Polsce w perspektywie kilkunastoletniego okresu, w latach 1994-2007. Przyjęty okres badań umożliwia porównanie zmian warunków otoczenia, wynikających z jednej strony z procesu transformacji polskiej gospodarki, a z drugiej - z akcesji do struktur europejskich. Ważnym aspektem badań będzie określenie stopnia i tendencji rozwojowych $\mathrm{w}$ badanej grupie przedsiębiorstw, w wymiarze ich rozwoju finansowego. Jako metodę badawczą zastosowano analizę danych statystycznych zebranych w statystyce i opracowaniach GUS.

Analizę i ocenę przedsiębiorstw w systemach gospodarczych można określić różnymi wskaźnikami, np. poprzez liczbę pracujących, liczbę przedsiębiorstw lub liczbę zatrudnionych. 
Wskaźniki te jako podstawowe mogą być zastosowane do wstępnej oceny sektorowej małych i średnich przedsiębiorstw. Jednak istotnym zagadnieniem jest ocena uzyskiwanych efektów ekonomiczno-finansowych.

\section{Aktywność inwestycyjna sektora MŚP}

Ważnym aspektem funkcjonowania małych i średnich przedsiębiorstw na rynku jest ich działalność inwestycyjna. Inwestycje warunkują właściwy rozwój gospodarki i są niezbędne do poprawy konkurencyjności poszczególnych jej działów. Skala inwestycji w gospodarce jest zazwyczaj dobrym odzwierciedleniem stanu i perspektyw rozwoju. Stosując to kryterium, lata wysokiego tempa inwestowania można określić jako okres ekspansji sektora przedsiębiorstw i dobrej koniunktury. Zahamowanie działań inwestycyjnych wiąże się zaś zazwyczaj z trudną sytuacją na rynku. Powszechnie uważa się, że bez inwestycji żaden podmiot społeczno-gospodarczy nie jest w stanie się rozwijać. Inwestycje to celowe wydatkowanie kapitału, skierowane na powiększenie korzyści materialnych i niematerialnych podmiotu gospodarującego. Inwestycje w sektorze MŚP są szczególnym rodzajem inwestowania w kontekście trwałego ich rozwoju. Zebranie informacji o procesie inwestycyjnym realizowanym przez sektor małej i średniej przedsiębiorczości ma istotne znaczenie dla kompleksowej oceny stanu faktycznego tego sektora. Konieczność prowadzenia inwestycji wynika z rosnącej konkurencyjności na rynku, ciaggle zmieniającego się otoczenia, nowych wyzwań, rosnących oczekiwań klientów. W dobie szybkiego postępu technicznego i konkurencji na rynku szansę przetrwania i rozwoju zapewniają przedsiębiorstwom takie cechy, jak: nowoczesność, innowacyjność, elastyczność i adaptacyjność. Temu wszystkiemu powinny służyć inwestycje (Roszkowska 2004).

Interpretowanie pojęcia inwestycji w teorii i praktyce gospodarczej należy do znacznie zróżnicowanych. Wśród podstawowych typów definicji inwestycji można wyróżnić szerokie i wąskie ich określenie. Najszersza i najbardziej ogólna definicja utożsamia inwestycje ze wszystkimi środkami i oszczędnościami w gospodarce przeznaczonymi na dalszy rozwój produkcji i usług, które nie zostały skonsumowane (Harmgardt, Tiedtke 1992). Szerokie rozumienie inwestycji to również wszelkie nakłady gospodarcze ponoszone na reprodukcję poszczególnych zasobów, tj. zasobów ludzkich, rzeczowych, pieniężnych, badawczych. Natomiast w węższym znaczeniu inwestycje to nakłady na przyrost i odtworzenie majątku rzeczowego w przedsiębiorstwie. Oznaczają zakup nowych środków trwałych, wartości niematerialnych i prawnych oraz modernizację już posiadanych. Można je zdefiniować jako wydatki środków finansowych na tworzenie majątku o określonej wielkości i strukturze. W wyniku inwestycji kapitał finansowy jest zamieniany na dobra rzeczowe i usługi, aby w późniejszych okresach uzyskać wpływy pieniężne. Inwestycje warunkują właściwy rozwój gospodarki i są niezbędne do poprawy konkurencyjności poszczególnych jej podmiotów. Są więc podstawowym czynnikiem i główną determinantą rozwoju przedsiębiorstwa (Safin 2008).

Inwestycje posiadają szereg charakterystycznych dla siebie cech, które wyróżniają je wśród innych działań przedsiębiorstwa. Określają one specyfikę inwestycji, która powinna być uwzględniona przy podejmowaniu decyzji inwestycyjnej przez przedsiębiorstwo. Wśród podstawowych cech inwestycji należy wymienić:

- ryzyko i niepewność realizacji inwestycji, zwłaszcza odnośnie odzyskania kapitału i czerpania z nich korzyści,

- konieczność zgromadzenia znacznych środków finansowych na realizację inwestycji,

- skomplikowaną i kosztochłonną procedurę przeprowadzenia rachunku inwestycyjnego,

- konieczność prowadzenia inwestycji dla rozwoju i przetrwania przedsiębiorstwa,

- długookresowość inwestycji,

- pozytywny wpływ na konkurencyjność przedsiębiorstwa i jego pozycję na rynku. 
Powyższe cechy inwestycji wskazują na złożony proces inwestowania w przedsiębiorstwie. Podmiot, który zamierza prowadzić inwestycję, musi się do niej dobrze przygotować pod względem organizacyjnym i finansowym. Te wymagania odnośnie inwestycji mają szczególne znaczenie dla małych i średnich przedsiębiorstw, gdyż posiadają najmniejsze możliwości ich całkowitego spełnienia. W warunkach nasyconego rynku oraz wysokiej i ciągle rozwijającej się techniki wybór właściwej, najbardziej opłacalnej koncepcji inwestowania w przedsiębiorstwie nie jest łatwy. W całym procesie jej przygotowywania trzeba więc wszechstronnie i umiejętnie posługiwać się odpowiednimi strategiami ich finansowania. W związku z tym przed każdą firmą powstają różnorodne możliwości podjęcia inwestycji realnych i finansowych. Każda firma musi jednak wypracować własną, odpowiednią w stosunku do swoich możliwości i potrzeb, strategię rozwoju.

Podstawowymi determinantami strategii inwestowania małego przedsiębiorstw są:

- kondycja ekonomiczno-finansowa przedsiębiorstwa,

- główna strategia rozwoju przedsiębiorstwa,

- dostępność do postępu techniczno-ekonomicznego,

- zdolność kredytowa banków,

- zdolność akumulacyjna przedsiębiorstwa,

- wykorzystanie zagranicznych środków kredytowych,

- infrastruktura systemu rynkowego - prawna, informacyjna, techniczna, finansowa, rynek kapitałowy, banki,

- ryzyko w danym horyzoncie czasowym.

Na działalność inwestycyjną przedsiębiorstw sektora małej i średniej skali działalności wpływa wiele różnych czynników, które mogą być zarówno stymulatorem, jak i hamulcem działalności inwestycyjnej. Uwarunkowania działalności inwestycyjnej małych i średnich przedsiębiorstw można podzielić na trzy zasadnicze grupy: uwarunkowania wewnętrzne, uwarunkowania lokalne i regionalne oraz warunkowania zewnętrzne. W grupie uwarunkowań zewnętrznych podkreśla się w szczególności znaczenie koniunktury gospodarczej, regulacje systemu finansowopodatkowego, wysokość stóp procentowych, dostępność usług bankowych, politykę kredytową banków, finansowe i pozafinansowe wsparcie rządu, finansowe wsparcie Unii Europejskiej (Alińska, Latoszek 2008). Aktywność inwestycyjną sektora MŚP w Polsce w latach 1994-2007 prezentuje tabela 1.

Wartość środków finansowych przeznaczanych na inwestycje w grupie polskich przedsiębiorstw od 1994 roku systematycznie wzrastała. Od 1999 roku poziom inwestycji utrzymuje się względnie na tym samym poziomie. W tym przedziale czasu wysokość nakładów wahała się od 47,3 mld zł do 60,4 mld zł rocznie. Najlepszy okres realizowania działalności inwestycyjnej przez sektor MŚP to 2003 rok z poziomem nakładów ponad 60,4 mld zł, a wcześniej rok 2000 z liczbą 53,2 mld zł. Analiza danych pokazuje zmienne tendencje dotyczące kształtowania się wielkości inwestycji w sektorze małej i średniej skali. Taka sytuacja świadczy o nieustabilizowanej sytuacji w badanej grupie przedsiębiorstw w zakresie polityki inwestycyjnej. Lata 2004-2005 to okres znacznego spadku nakładów na inwestycje do poziomu 44 mld zł. Najmniej korzystny pod tym względem okazał się rok 2002. W 2006 roku poziomu realizowanych zadań inwestycyjnych znacząco się zwiększył i wrócił do nakładów z 2000 roku.

Biorąc pod uwagę poziom inwestycji ze względu na wielkość przedsiębiorstwa mierzoną liczbą zatrudnionych, należy odnotować fakt, iż w grupie mikroprzedsiębiorstw oraz przedsiębiorstw małych poziom realizowanych inwestycji jest zbliżony. Korzystniejszą relację w zakresie zwiększania nakładów inwestycyjnych odnotowały najmniejsze podmioty gospodarujące. Stały i zdecydowanie najwyższy poziom inwestycji - trzy a nawet czterokrotny, stwierdzono w grupie przedsiębiorstw największych (zatrudniających powyżej 50 pracowników). 
Tab. 1. Nakłady inwestycyjne sektora MŚP ogółem (w mln zł)

\begin{tabular}{|c|c|c|c|c|c|c|}
\hline \multirow{2}{*}{$\begin{array}{c}\text { Przedsiębiorstwa } \\
\text { ogółem }\end{array}$} & \multirow{2}{*}{$\begin{array}{c}\text { Przedsiębiorstwa } \\
\text { MŚP }\end{array}$} & \multicolumn{5}{|c|}{ Z liczbą zatrudnionych: } \\
\hline & & $\begin{array}{c}0-5^{*} \\
\text { (mikro) }\end{array}$ & $6-50$ & $0-50$ & $51-250$ & ponad 250 \\
\hline \multicolumn{7}{|c|}{1994} \\
\hline 24196,0 & 8558,8 & $\begin{array}{c}\text { brak } \\
\text { danych }\end{array}$ & $\begin{array}{c}\text { brak } \\
\text { danych }\end{array}$ & 5573,4 & 2985,4 & 15637,2 \\
\hline \multicolumn{7}{|c|}{1995} \\
\hline 35357,7 & 12718,0 & $\begin{array}{c}\text { brak } \\
\text { danych }\end{array}$ & $\begin{array}{c}\text { brak } \\
\text { danych }\end{array}$ & 8081,7 & 4636,4 & 22639,7 \\
\hline \multicolumn{7}{|c|}{1996} \\
\hline 49249,8 & 18396,9 & $\begin{array}{c}\text { brak } \\
\text { danych }\end{array}$ & $\begin{array}{c}\text { brak } \\
\text { danych }\end{array}$ & 10627,7 & 7769,2 & 30852,9 \\
\hline \multicolumn{7}{|c|}{1997} \\
\hline 68490,8 & 28540,1 & $\begin{array}{c}\text { brak } \\
\text { danych }\end{array}$ & $\begin{array}{c}\text { brak } \\
\text { danych }\end{array}$ & 15683,6 & 12856,5 & 39950,7 \\
\hline \multicolumn{7}{|c|}{1998} \\
\hline 88080,6 & 38932,6 & $\begin{array}{c}\text { brak } \\
\text { danych }\end{array}$ & $\begin{array}{c}\text { brak } \\
\text { danych }\end{array}$ & 19592,9 & 19339,8 & 49147,9 \\
\hline \multicolumn{7}{|c|}{ 1999* } \\
\hline 101099,6 & 47314,8 & 11598,4 & 13808,2 & 25406,6 & 21908,2 & 53784,8 \\
\hline \multicolumn{7}{|c|}{2000} \\
\hline 106328,3 & 53190,5 & 15220,6 & 13391,1 & 28611,7 & 24578,8 & 53137,9 \\
\hline \multicolumn{7}{|c|}{2001} \\
\hline 93259,7 & 44975,2 & 11499,2 & 14456,1 & 25955,3 & 19019,9 & 48284,5 \\
\hline \multicolumn{7}{|c|}{2002} \\
\hline 72229,1 & 31612,9 & 9889,8 & 8370,3 & 18260,1 & 13352,8 & 40616,2 \\
\hline \multicolumn{7}{|c|}{2003} \\
\hline 108614,7 & 60383,5 & 26262,5 & 13660,3 & 39922,8 & 20460,7 & 48231,2 \\
\hline \multicolumn{7}{|c|}{2004} \\
\hline 90300,0 & 44910,9 & 11342,6 & 11859,4 & 23202,0 & 21708,9 & 45389,1 \\
\hline \multicolumn{7}{|c|}{2005} \\
\hline 99826,7 & 44033,8 & 11790,1 & 10859,4 & 22649,5 & 21384,3 & 55792,9 \\
\hline \multicolumn{7}{|c|}{2006} \\
\hline 113740,9 & 54493,3 & 14125,5 & 12720,1 & 26845,6 & 27647,7 & 59247,6 \\
\hline \multicolumn{7}{|c|}{2007} \\
\hline 118518,9 & 51072,2 & 9608,7 & 12653,4 & 28810,1 & 31878,2 & 74670,1 \\
\hline
\end{tabular}

*od 1999 roku obowiązuje nowe kryterium - wyróżnienia mikroprzedsiębiorstw zatrudniających do 9 osób

Źródło: Zmiany strukturalne grup podmiotów gospodarki narodowej, GUS, Warszawa, dane z odpowiednich lat. 
Ważnym elementem badań jest określenie stopnia realizacji zadań i inwestycji na tle ogółu przedsiębiorstw. Charakteryzuje on poziom zaangażowania tego sektora w przemianach systemowych. Udział małych i średnich przedsiębiorstw w nakładach inwestycyjnych ogółu przedsiębiorstw przedstawia tabela 2.

Tab. 2. Udział małych i średnich przedsiębiorstw w nakładach inwestycyjnych w latach 1994-2007

\begin{tabular}{|c|c|}
\hline Lata & $\begin{array}{c}\text { Udzial MŚP w nakładach } \\
\text { inwestycyjnych ogólem (\%) }\end{array}$ \\
\hline 1994 & 35,3 \\
\hline 1995 & 36,0 \\
\hline 1996 & 37,4 \\
\hline 1997 & 41,7 \\
\hline 1998 & 44,2 \\
\hline 1999 & 46,8 \\
\hline 2000 & 50,0 \\
\hline 2001 & 48,2 \\
\hline 2002 & 43,8 \\
\hline 2003 & 55,6 \\
\hline 2004 & 49,7 \\
\hline 2005 & 44,1 \\
\hline 2006 & 47,9 \\
\hline 2007 & 48,3 \\
\hline
\end{tabular}

Źródło: na podstawie danych tabeli 1.

Udział nakładów inwestycyjnych ogółem dla sektora MŚP wykazywał w analizowanym okresie dobry poziom wskazań. Oscylował on w zakresie od 35,3\% do 48,3\%, a od $1997 \mathrm{r}$. przekroczył 41\%. Wyrównany poziom tego parametru świadczy o znacznym udziale sektora indywidualnych przedsiębiorstw w zwiększaniu potencjału rozwojowego i jego trwałym rozwoju oraz o wyrównanej rywalizacji w grupie wszystkich przedsiębiorstw, a także o korzystnych postawach aktywności inwestycyjnej.

W badanym okresie przedsiębiorstwa małej i średniej skali zwracały znaczną uwagę na działalność inwestycyjną. Licząc rachunkiem skumulowanym, MŚP przeznaczyły w tym czasie na realizację inwestycji ponad $530 \mathrm{mld}$ zł. W ten sposób posiadają znaczący udział w inwestycjach ogółem oraz większościowy udział wśród przedsiębiorstw prywatnych. Dane te potwierdzają dużą rolę nakładów inwestycyjnych w prowadzonej działalności gospodarczej przez ten sektor. Świadomość inwestycyjna MŚP przejawia się w potrzebie ponoszenia takich wydatków, a postawa ta służy rozwojowi danego sektora.

Dominującą w Polsce formą finansowania inwestycji w sektorze małej i średniej przedsiębiorczości są od lat środki własne. Świadczy to niewątpliwie o trudnym dostępie przedsiębiorstw z sektora MŚP do kapitałów obcych. Małe przedsiębiorstwa w przeciwieństwie do dużych ponoszą odmienne koszty pozyskiwania kapitału obcego, głównie wyższe koszty obsługi zadłużenia. Występuje tu zjawisko ich dyskryminacji. Do najważniejszych powodów dyskryminacji małych firm jako kredytobiorców należą koszt obsługi banku oraz ryzyko 
kredytowe małych firm. Koszty obsługi kredytu w dużym stopniu mają charakter kosztów stałych. Niezależnie od wielkości kredytu, pracownicy banków wykonują podobne czynności w zakresie procedury przyznania kredytu oraz dalszej jego kontroli. Jednostkowy koszt mniejszych kredytów jest w tym wypadku wyższy niż w przypadku kredytów dużych. Powoduje to wzrost oprocentowania i opłat związanych z kredytami dla małych przedsiębiorstw, a także ogólny spadek zainteresowania banków kredytowaniem sektora MŚP i koncentrację na segmencie przedsiębiorstw korporacyjnych. Drugim podstawowym powodem dyskryminacji małych firm jako kredytobiorców jest wysokie ryzyko ich bankructwa. Kredytowanie małych firm, które charakteryzują się krótką historią działalności gospodarczej lub też dopiero rozpoczynają działalność, jest obciążona większym ryzykiem, gdyż firmy te nie zostały jeszcze W wystarczającym stopniu zweryfikowane przez rynek (Waniak-Michalak 2007). Do najczęściej wykorzystywanych sposobów finansowania działalności przedsiębiorstw ze źródeł obcych należą: kredyt kupiecki, kredyt bankowy oraz leasing. Dominującą formę finansowania stanowią wśród nich zobowiązania handlowe. Nie jest to sytuacja korzystna, gdyż zwiększa ryzyko niewypłacalności przedsiębiorstwa oraz nie sprzyja akumulacji.

Badania z ostatnich lat wskazują także na pewne symptomy zmian. Udział firm realizujących swoje inwestycje ze środków własnych w porównaniu do lat poprzednich nieznacznie się zmniejszył, przy jednoczesnym wzroście udziału nakładów inwestycyjnych z kredytów krajowych i pożyczek bankowych. Odnotowano także nieznaczny wzrost udziału nakładów inwestycyjnych finansowanych ze środków zagranicznych (Żołnierski, Zadura 2008). Coraz większą rolę wydają się również odgrywać dotacje z Unii Europejskiej, co w sposób bezpośredni związane jest z faktem wstąpienia Polski do struktur unijnych i uzyskaniem dostępu do funduszy strukturalnych (Bednarczyk 2004). Obserwowany wzrost zainteresowania dotacjami, który przejawia się m.in. w rosnącej liczbie składanych wniosków, pozwala oczekiwać, że ta forma finansowania będzie nabierać coraz większego znaczenia. Integracja z rynkiem wspólnotowym rodzi także nadzieje na szerszy rozwój finansowania typu venture capital. Formami finansowania, które cieszą się zainteresowaniem, w szczególności przedsiębiorstw będących w początkowej fazie rozwoju, są mikropożyczki oferowane przez fundusze pożyczkowe oraz leasing. Dają one możliwość pozyskania środków pieniężnych oraz dóbr trwałych bez konieczności posiadania określonego stażu działalności oraz zabezpieczeń, które byłyby niezbędne w przypadku ubiegania się o kredyt bankowy. Należy zaznaczyć, że leasing jest uniwersalnym źródłem finansowania, które jest wykorzystywane zarówno przez przedsiębiorstwa mikro, małe, jak i średnie. W przypadku leasingu występuje dodatkowo efekt tarczy podatkowej, która powoduje zmniejszenie zobowiązań z tytułu podatku - oczywiście przy założeniu, że firma jest rentowna. Istotnym atutem finansowania działalności poprzez leasing jest również możliwość spłaty zobowiązań z tytułu rat leasingowych ze środków pieniężnych wygenerowanych dzięki użytkowaniu leasingowanego dobra - bez wpływu na strukturę właścicielską i związany z tym udział w zysku osób trzecich. Nie bez znaczenia wydaje się być również fakt, że zarządzanie przedsiębiorstwem pozostaje w pełni w rękach dotychczasowych właścicieli.

Z obserwacji i monitoringu kondycji sektora polskiej przedsiębiorczości wynika, że do 2006 roku małe i średnie firmy bardzo wyraźnie działały w krótkim horyzoncie czasowym (PKPP Lewiatan 2008). Wykorzystywały maksymalnie posiadane zasoby i dopiero wtedy podejmowały inwestycje, których celem było zwiększenie możliwości produkcyjnych. Nie planowały długookresowo, ponieważ postrzegały ramy prawne, w których działają, za nieprzewidywalne, niestabilne, a tym samym podnoszące ryzyko działalności gospodarczej. Koncentrując się na krótkim okresie chciały wykorzystać dobrą koniunkturę gospodarczą. Jeżeli inwestowały, to przede wszystkim w składniki majątkowe pozwalające im zwiększyć produkcję i świadczenie 
usług. Rezygnując z wprowadzania nowych produktów i usług na rynek, tym samym w krótkim okresie czasu poprawiała swoją kondycję ekonomiczną ,a głównie rentowność prowadzonej działalności. Jedyną strategią konkurowania była cena. Ostatnie lata wskazują na zmianę strategii małych i średnich firm. Znacznie większe znaczenie w budowaniu ich pozycji konkurencyjnej na rynku ma dzisiaj jakość, specjalizacja, umiejętność dopasowywania produktów i usług do potrzeb klientów. Są znacznie bardziej zainteresowane inwestowaniem, przy czym inwestują coraz więcej w nowe technologie.

\section{Ocena pozycji ekonomicznej sektora małych i średnich przedsiębiorstw}

Dążąc do oceny kondycji ekonomiczno-finansowej MŚP należy zwrócić uwagę głównie na efektywność gospodarowania posiadanymi zasobami oraz stan ekonomiczno-finansowy przedsiębiorstw. Oznacza to konieczność przeprowadzenia analizy przynajmniej w takich obszarach, jak osiagnięte przychody, koszty własne działalności, sytuacja finansowa, sytuacja rynkowa. Podstawą pozyskiwania informacji o kondycji ekonomiczno-finansowej MŚP jest ewidencja księgowa. Należy zaznaczyć, iż w Polsce w większości przypadków jest to ewidencja uproszczona, prowadzona głównie dla celów podatkowych i koncentrująca się na pomiarze wybranych wyników i zasobów oraz w mniejszym stopniu pełna księgowość. Ewidencja uproszczona jest prowadzona na podstawie ryczałtu ewidencjonowanego, karty podatkowej i podatkowej księgi przychodów i rozchodów. Ewidencja podatkowa ułatwia prowadzenie rozliczeń i jednocześnie upraszcza rzeczywisty obraz przedsiębiorstwa z uwagi na znaczne ograniczenie zapisu zdarzeń i ich prostą klasyfikację. Na bazie tylko tego typu ewidencji ocena sektorowa w tym przypadku jest w znacznym stopniu ograniczona. Biorąc tylko pod uwagę informacje o charakterze obligatoryjnym zawarte w książce przychodów i rozchodów oraz uzupełniającej ją dokumentacji możliwa jest analiza niektórych czynników kształtujących kondycję ekonomiczno-finansową przedsiębiorstwa. Książka przychodów i rozchodów identyfikuje w zasadzie tylko dwie grupy przychodów. Księgi rachunkowe wydzielają trzy grupy przychodów, natomiast ewidencja za pomocą karty podatkowej ogranicza zysk do wersji kasowej. Zestawienie podstawowych wyników finansowych MŚP przedstawia tabela 3.

Analizując sytuację małych i średnich przedsiębiorstw pod względem osiaganych przychodów oraz kosztów należy stwierdzić, iż są one bardzo zróżnicowane. W 1994 roku przychody tego sektora ze sprzedaży produktów, towarów i usług z podstawowej działalności operacyjnej (obroty) wynosiły $91 \mathrm{mld}$ zł i w ciągu trzynastu lat wzrosły znacząco. W ostatnim roku analizowanego okresu obroty ze sprzedaży produktów, towarów i usług z całego sektora MŚP osiągnęły wartość 612,6 mld zł. Przychody ze sprzedaży ogółem (według cen bieżących w kolejnych latach w porównaniu z rokiem poprzednim jako bazowym) wzrastały systematycznie przy średniorocznym tempie wzrostu od 20,2 \% do 37,5\%. Uzyskana dynamika wyraźnie odnotowała lepsze wskazania w latach 1999-2000 oraz 2001-2004. Odnosząc uzyskane przychody do takich parametrów, jak przedsiębiorstwo czy liczba zatrudnionych, należy wskazać, że lepsze parametry ma wielkość obrotów generowana przez zakład traktowany jako całe przedsiębiorstwo. Lepsza jest również dynamika zmian w czasie. W wartościach bezwzględnych wzrost ten jest ponad czterokrotny. Szczególnie wysoką sprzedaż odnotowano w 2007 i 2008 roku. Przeliczając wielkość generowanych przychodów ze sprzedaży na jednego zatrudnionego zauważa się, że dynamika tych zmian jest dwukrotnie mniejsza. Wielkości te mogą świadczyć o wzroście skali działalności podmiotów o utrwalonej strukturze działania i jednocześnie o zwiększaniu efektywności pracy. Blisko połowa MŚP osiaga wyższe przychody ze sprzedaży niż w pierwszych latach po transformacji. Prawie połowa osiaga także co roku wyższe zyski. Maleje liczba tych przedsiębiorstw, które tracą udziały w rynku. 


\begin{tabular}{|c|c|c|c|c|c|c|c|c|}
\hline ڤ్̀ે & $\begin{array}{l}\overrightarrow{0} \\
\hat{0} \\
\stackrel{0}{\sigma}\end{array}$ & $\underset{\sim}{\stackrel{n}{n}}$ & $\begin{array}{r}\hat{\infty} \\
\stackrel{0}{n}\end{array}$ & $\begin{array}{l}\vec{n} \\
\bar{n} \\
\infty \\
\tilde{n}\end{array}$ & $\underset{\vec{n}}{\stackrel{\vec{m}}{ }}$ & $\begin{array}{l}\hat{\delta} \\
\stackrel{0}{0}\end{array}$ & $\begin{array}{l}\text { तु } \\
\text { - }\end{array}$ & $\begin{array}{l}\text { ले } \\
\text { సे }\end{array}$ \\
\hline ‡ั๋ & $\begin{array}{l}\stackrel{0}{2} \\
\stackrel{f}{f} \\
i n\end{array}$ & 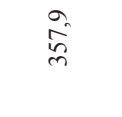 & กิ & $\begin{array}{l}0 \\
80 \\
\stackrel{8}{6} \\
0\end{array}$ & ì & ก̂ & $\overrightarrow{\text { ๙े }}$ & $\begin{array}{l}\stackrel{0}{\circ} \\
\stackrel{\overrightarrow{0}}{0} \\
\dot{0}\end{array}$ \\
\hline$\stackrel{\text { ڤิ }}{\circ}$ & $\begin{array}{l}\stackrel{i}{0} \\
\stackrel{0}{0} \\
\stackrel{n}{n}\end{array}$ & $\begin{array}{l}\text { D } \\
\text { లె } \\
\text { m. }\end{array}$ & $\begin{array}{l}\infty \\
\vec{\Xi}\end{array}$ & $\begin{array}{l}0 \\
\stackrel{8}{\circ} \\
\stackrel{\infty}{+\infty}\end{array}$ & $\overrightarrow{\text { ô }}$ & $\stackrel{\infty}{\stackrel{f}{\Xi}}$ & $\vec{\jmath}$ & $\begin{array}{l}\text { ते } \\
\text { fै } \\
\text { fे }\end{array}$ \\
\hline ఫ્ડ & $\begin{array}{l}\infty \\
\hat{n} \\
\tilde{N} \\
\hat{n}\end{array}$ & 宑 & $\begin{array}{l}n \\
\tilde{n}\end{array}$ & 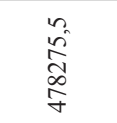 & $\hat{\stackrel{D}{े}}$ & $\vec{F}$ & $\begin{array}{l}0 \\
\stackrel{\infty}{0}\end{array}$ & 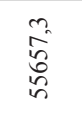 \\
\hline ๕్̊ & \begin{tabular}{l}
\multirow{2}{\circ}{} \\
2 \\
2 \\
$\frac{\sigma}{8}$
\end{tabular} & $\begin{array}{l}\hat{0} \\
\infty \\
\infty \\
i\end{array}$ & $\begin{array}{l}\stackrel{J}{~} \\
\underset{J}{J}\end{array}$ & \begin{tabular}{l}
$n$ \\
\multirow{2}{n}{} \\
$\tilde{n}$ \\
$\tilde{y}$
\end{tabular} & $\begin{array}{l}\text { ָे } \\
\text { ָे }\end{array}$ & 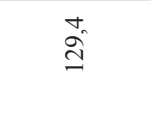 & $\begin{array}{l}\infty \\
\&\end{array}$ & 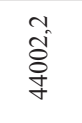 \\
\hline 气ิ & 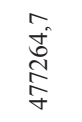 & $\underset{\text { ते }}{\text { ஸे }}$ & 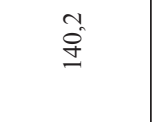 & 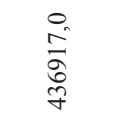 & $\begin{array}{l}\text { ते } \\
\infty \\
\stackrel{n}{n}\end{array}$ & $\begin{array}{l}\text { m. } \\
\stackrel{\text { I }}{\beth}\end{array}$ & $\frac{0}{a}$ & $\begin{array}{l}\stackrel{0}{\circ} \\
\stackrel{\vec{D}}{\sigma} \\
\stackrel{\sigma}{\sigma}\end{array}$ \\
\hline క్ట̆ & $\begin{array}{l}2 \\
2 \\
2 \\
2 \\
\text { ñ }\end{array}$ & $\begin{array}{l}\overrightarrow{\mathbb{D}} \\
\stackrel{\sim}{\sim}\end{array}$ & $\stackrel{\stackrel{\sim}{\exists}}{\underset{\Xi}{\Xi}}$ & $\begin{array}{l}\text { के } \\
\text { ते } \\
\text { Oे }\end{array}$ & 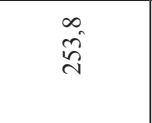 & $\overrightarrow{\widehat{I}}$ & $\overrightarrow{8}$ & $\begin{array}{l}3 \\
\overbrace{}^{2} \\
\tilde{p}^{n} \\
y\end{array}$ \\
\hline ఫ్సి & 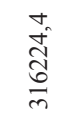 & \begin{tabular}{l}
$\infty$ \\
\multirow{1}{1}{} \\
$\infty$
\end{tabular} & $\begin{array}{c}\text { ra } \\
\infty\end{array}$ & 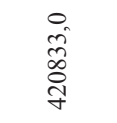 & $\begin{array}{l}\text { 我 } \\
\underset{\sim}{\sim}\end{array}$ & $\begin{array}{l}0 \\
\text { İ }\end{array}$ & ڤै & $\begin{array}{l}n \\
\frac{n}{2} \\
2 \\
\frac{n}{y}\end{array}$ \\
\hline बे & 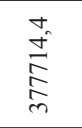 & $\overrightarrow{\vec{v}}$ & $\stackrel{\infty}{=}$ & $\begin{array}{l}\infty \\
\substack{i \\
i} \\
\infty \\
m\end{array}$ & $\stackrel{+}{\circ}$ & & $\stackrel{+}{\circ}$ & 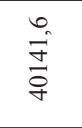 \\
\hline$\stackrel{\circ}{\circ}$ & $\begin{array}{l}2 \\
\stackrel{n}{2} \\
\frac{n}{2}\end{array}$ & $\stackrel{\cong}{\Xi}$ & ì & 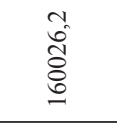 & مे & है & $\tilde{\infty}_{\infty}^{n}$ & $\begin{array}{l}\stackrel{N}{n} \\
\stackrel{n}{n}\end{array}$ \\
\hline$\hat{\sigma}$ & $\begin{array}{l}\stackrel{+}{0} \\
\stackrel{0}{\infty} \\
\stackrel{\Xi}{=}\end{array}$ & $\begin{array}{l}n \\
\stackrel{1}{I}\end{array}$ & $\begin{array}{l}0 \\
\stackrel{i}{i}\end{array}$ & $\begin{array}{l}\stackrel{m}{\stackrel{2}{\xi}} \\
\stackrel{\Xi}{\Xi}\end{array}$ & से & $\frac{1}{n}$ & $\begin{array}{l}\infty \\
\infty^{\infty}\end{array}$ & $\overrightarrow{\overrightarrow{0}}$ \\
\hline ڤั & $\begin{array}{l}\infty \\
\tilde{N} \\
\widehat{\sigma} \\
\stackrel{6}{n}\end{array}$ & 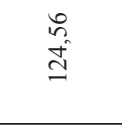 & $\vec{r}$ & 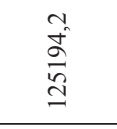 & $\hat{a}$ & $\begin{array}{l}n \\
\infty^{n} \\
n\end{array}$ & $\vec{\infty}$ & $\begin{array}{l}0 \\
\infty \\
\stackrel{0}{\Xi} \\
\stackrel{m}{\Xi}\end{array}$ \\
\hline$\stackrel{\circ}{\sigma}$ & $\begin{array}{l}\stackrel{0}{n} \\
\hat{n} \\
0\end{array}$ & $\begin{array}{l}0 \\
\stackrel{0}{0}\end{array}$ & $\hat{\vec{n}}$ & $\begin{array}{l}0 \\
\infty \\
0 \\
\infty \\
\infty\end{array}$ & $\stackrel{\circ}{\stackrel{\circ}{\therefore}}$ & $\stackrel{m}{\stackrel{m}{f}}$ & $\stackrel{\sim}{\underset{t}{*}}$ & $\begin{array}{l}0 \\
i \\
\infty \\
\infty \\
\infty \\
\sim\end{array}$ \\
\hline ڤ̆ & $\begin{array}{l}\text { ñ } \\
\text { ó } \\
\text { oे }\end{array}$ & $\frac{\hat{\alpha}}{\hat{\infty}}$ & $\begin{array}{l}\infty \\
\dot{q}\end{array}$ & $\begin{array}{l}n \\
n \\
0 \\
0 \\
n \\
n\end{array}$ & $\stackrel{m}{\approx}$ & $\stackrel{n}{F}$ & $\stackrel{\leftrightarrow}{\infty}$ & $\begin{array}{l}\stackrel{0}{a} \\
\stackrel{\Xi}{\underline{n}}\end{array}$ \\
\hline 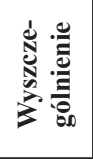 & 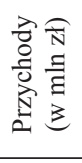 & 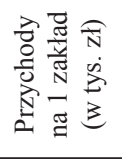 & 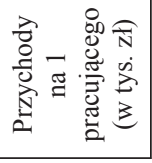 & 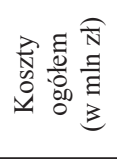 & 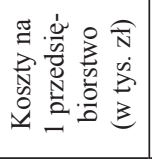 & 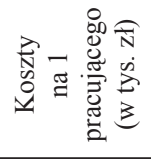 & 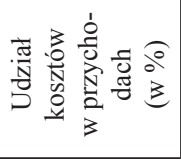 & 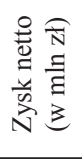 \\
\hline
\end{tabular}


Istotnym wskaźnikiem analiz ekonomicznych wszystkich podmiotów gospodarujących jest poziom i struktura ponoszonych kosztów, które są ściśle związane z prowadzoną działalnością statutową. Koszty są pierwszą kategorią wynikową i warunkują w dalszym etapie uzyskanie przychodów. W ujęciu bezwzględnym poziom kosztów całkowitych w badanym okresie czasu systematycznie wrastał, wykazując podobną korelację do zmian w wartości obrotów firm. Wynika to z jednej strony ze wzrostu skali działalności i powiązanych z nią zmian kosztów bezpośrednich, a drugiej - może świadczyć o wyższej kosztochłonności prowadzonych produkcji wynikających z poprawy jakości i konieczności wdrażania nowych technologii. Informacji o tym dostarcza wskaźnik kosztów działalności do przychodów, tzw. wskaźnik kosztochłonności. Po 2000 roku odnotowano w przedsiębiorstwach wzrost udziału kosztów. Od początku 2006 dynamika kosztów jest wyższa niż dynamika przychodów. Przyczyny wzrostu kosztów tkwią przede wszystkim we wzroście wynagrodzeń, które rosną znacznie szybciej niż koszty przedsiębiorstw ogółem. Przedsiębiorstwa wydają także znacznie więcej na usługi obce. Jest to efekt wydzielania coraz większych części własnych obszarów biznesowych poza firmę dla szukania wyższej efektywności. Jednak na te decyzje wpływ mają także wysokie pozapłacowe koszty pracy i nieelastyczne prawo pracy, które w dobie działania opartego na projektach zmuszają do ograniczania wzrostu zatrudnienia we własnej firmie.

Wskaźnik kosztów działalności do przychodów ze sprzedaży informuje o tym, jaki był procent kosztów w osiągniętych przychodach. Udział kosztów w przychodach wykazywał w badanym sektorze względnie stały poziom. W 1994 roku koszty stanowiły 83,4\% przychodów. W kolejnych latach spadły one nieznacznie, nadal wykazując poprawne relacje. Najlepszą relację kosztów do przychodów ogółem odnotowano w 1995 roku, gdzie wskaźnik kosztochłonności prowadzonej działalności osiągnął poziom 74,2\%. W przedostatnich dwóch latach badanego przedziału czasowego wskaźnik kosztów działalności do przychodów ze sprzedaży wzrósł wyraźnie do ponad 93\% i zbliżył sytuację małych i średnich podmiotów do przedsiębiorstw większej skali. Zastanawiające jest zjawisko spadku udziału kosztów w ostatnim roku do $86,2 \%$ i osiągnięcie takiego samego poziomu wskazań, jak w drugiej połowie lat 90 . Był to okres poprzedzający kryzys gospodarczy na arenie międzynarodowej. Dalsze analizy tego parametru mogą wskazać na pozytywne działania zachowawcze indywidualnych przedsiębiorstw i strategie ukierunkowane na przetrwanie w warunkach niepewności.

Zebrane dane o kosztach i przychodach mogą być podstawą dalszego wnioskowania i analiz. Mogą być bazą do obliczenia wskaźników finansowych charakteryzujących kondycję ekonomiczną badanej grupy. Najprostszą i najczęściej wykorzystywaną metodą do syntetycznej oceny działalności przedsiębiorstwa jest metoda wskaźnikowa. Wykorzystując tę metodę należy tak dobrać wskaźniki, aby uzyskać zbiór powiązanych ze sobą informacji o wskazanych obszarach działalności przedsiębiorstwa (Gołębiowski, Tłaczała 2005). W małych przedsiębiorstwach prowadzących tylko ewidencję w oparciu o książkę przychodów i rozchodów obliczenie szeregu wskaźników jest niemożliwe. Przedsiębiorca prowadzący ewidencję objętą prawem podatkowym może ocenić kondycję ekonomiczno-finansową własnej firmy jedynie w ograniczonym zakresie. Zwrócić należy zatem uwagę na podstawowy obszar analiz, a więc rentowność przedsiębiorstwa. Przedsiębiorcy dysponujący tylko ewidencją podatkową nie mają niestety możliwości obliczenia większości wskaźników. Na bazie posiadanych informacji trudna jest również ocena płynności finansowej. W tym zakresie brak jest informacji o należnościach, zobowiązaniach, posiadanym majątku obrotowym, a nawet o zasobach gotówkowych. W tym przypadku takie informacje posiada jedynie właściciel firmy. 
Tab. 4. Analiza finansowa małych i średnich przedsiębiorstw za pomocą wybranych wskaźników

\begin{tabular}{|c|c|c|c|c|c|c|c|c|c|c|c|c|c|c|}
\hline $\begin{array}{c}\text { Wyszczegól- } \\
\text { nienie }\end{array}$ & $\mathbf{1 9 9 4}$ & $\mathbf{1 9 9 5}$ & $\mathbf{1 9 9 6}$ & $\mathbf{1 9 9 7}$ & $\mathbf{1 9 9 8}$ & $\mathbf{1 9 9 9}$ & $\mathbf{2 0 0 0}$ & $\mathbf{2 0 0 1}$ & $\mathbf{2 0 0 2}$ & $\mathbf{2 0 0 3}$ & $\mathbf{2 0 0 4}$ & $\mathbf{2 0 0 5}$ & $\mathbf{2 0 0 6}$ & $\mathbf{2 0 0 7}$ \\
\hline $\begin{array}{c}\text { Wskaźnik } \\
\text { rentowności } \\
\text { sprzedaży (\%) }\end{array}$ & 17,0 & 26,0 & 20,0 & 21,0 & 16,3 & 10,6 & 13,2 & 11,9 & 12,5 & 12,5 & 10,2 & 7,9 & 8,9 & 13,7 \\
\hline $\begin{array}{c}\text { Wskaźnik } \\
\text { zysku brutto } \\
\text { do kosztów } \\
\text { działalności } \\
(\%)\end{array}$ & 20,0 & 35,0 & 25,1 & 26,9 & 20,1 & 11,9 & 15,2 & 13,6 & 14,3 & 13,5 & 12,0 & 8,9 & 9,9 & 14,9 \\
\hline $\begin{array}{c}\text { Wskaźnik } \\
\text { kosź́w } \\
\text { działalności } \\
\text { do przychodów } \\
\text { ze sprzedaży } \\
(\%)\end{array}$ & 83,4 & 74,2 & 80,1 & 78,8 & 83,5 & 89,4 & 90,2 & 90,1 & 91,6 & 90,8 & 89,6 & 93,1 & 93,1 & 86,2 \\
\hline
\end{tabular}

Źródło: opracowanie własne na podstawie Działalność małych przedsiębiorstw z lat 1994-1998, opracowanie statystyczne lat 1999-2004, Działalność przedsiębiorstw niefinansowych z lat 2005-2008 Wydawnictwo GUS, Warszawa.

Do oceny efektywności działań realizowanych w przedsiębiorstwie i jego zdolności do generowania zysku z majątku służą wskaźniki rentowności. Przedstawiają one relacje wyniku finansowego liczonego na różnych poziomach działalności gospodarczej do efektów wyrażonych przychodami lub różnego rodzaju nakładów. Jednym z tego typu wskaźników jest wskaźnik rentowności sprzedaży określany również jako wskaźnik rentowności handlowej. Wskaźniki rentowności sprzedaży są stosunkiem procentowym zysku do przychodu lub kosztów. Określają one w swej istocie udział odpowiedniego wyniku finansowego w wartości uzyskanej ze sprzedaży produktów, towarów oraz realizowanych operacji finansowych. Ich prezentację przedstawia tabela $\mathrm{nr}$ 4. Wskaźnik rentowności sprzedaży wskazywał w badanej grupie docelowej zawsze liczbę dodatnią. Oznacza to, że w analizowanych przedsiębiorstwach wzrastała efektywność sprzedaży, a każda zaangażowana złotówka generowała dodatkowy zysk. W 1995 roku wskaźnik rentowności sprzedaży wynosił 26\% i był on najwyższy w analizowanych latach. W 1998 roku obniżył się do poziomu 16\%, w kolejnych latach systematycznie zmniejszając wartość wskazań. Jedna złotówka uzyskana ze sprzedaży produktów, towarów i usług wygenerowała w okresie zysk o wartości od 0,07 zł do 0,26 zł. Od 1998 roku obserwowane jest zjawisko spadku rentowności większości przedsiębiorstw MŚP, zarówno średnich, jak i małych. Wiąże się to z wieloma czynnikami związanymi ze wzrostem obciążeń finansowych oraz z generalnym spadkiem popytu. Duży, niekorzystny wpływ na rentowność miało również załamanie się rynku wschodniego, mniejszy popyt zewnętrzny, podnoszony przez przedsiębiorców problem importu tanich towarów. Zdecydowanie dobre wyniki finansowe osiagnęły małe i średnie firmy związane z energetyką oraz z łącznością, podnosząc globalne wyniki finansowe ogółu firm przemysłowych i transportowych. Odbicie wskaźnika zyskowności miało miejsce bezpośrednio przed akcesją naszego kraju ze strukturami europejskimi, ale nie wróciło do najlepszych notowań. Wyraźną poprawę odnotowano w ostatnim okresie czasowym. 
Kolejny zastosowany wskaźnik uwzględnia w obliczeniach koszty uzyskania przychodu i określa relację zysku niepodzielonego do koszów prowadzonej działalności. W badanych przedsiębiorstwach wskaźnik ten wykazuje tendencje malejącą. Najwyższe wskazanie tego parametru to poziom wygenerowania przez jedną złotówkę poniesionych nakładów 0,35 zł zysku, natomiast najniższe notowania stwierdza się na poziomie 0,09 zł. Obecnie warunki prowadzenia małego biznesu znacznie różnią się od tych, jakie występowały na początku okresu transformacji. Czas szybkich zysków powiązany z uzupełnianiem najłatwiejszych nisz rynkowych przeminął. Wzrost konkurencji spowodował, że małej i średniej firmie jest znacznie trudniej zarówno wejść na rynek, jak i utrzymać się na nim. Wymagać to będzie podjęcia innych działań adaptacyjnych, koncentrujących się na wdrażaniu innowacyjności i poprawie jakości. Analizując sytuację przedsiębiorstw w ujęciu ogólnym można zauważyć, że podjęte $\mathrm{w}$ odpowiednim okresie decyzje organizacyjne przyniosły dodatni efekt finansowy firm w przeliczeniu na jednostkę poniesionych nakładów.

Podsumowując rozważania należy wskazać, iż małe i średnie firmy charakteryzują się wyższą rentownością obrotu niż firmy duże i są lepiej przygotowane na zjawiska recesji. W okresie kryzysu na światowych rynkach finansowych oraz osłabienia koniunktury gospodarczej na świecie ich postawy co do dalszego rozwoju były optymistyczne. Z badań wynika, że małe i średnie przedsiębiorstwa miały we wrześniu 2008 r. ogromne plany dotyczące swojej działalności w 2009 r. Prawie 75\% MŚP planowało wzrost przychodów, ponad 70\% oczekiwało wzrostu zysków, jedna trzecia uważała, że ich udziały w rynku wzrosną ${ }^{1}$. Ponad $40 \%$ planowało inwestycje, a blisko $40 \%$ - wprowadzenie nowych produktów i usług na rynek. Małe i średnie firmy planowały także wzrost nakładów na zakup nowych technologii. Oczekiwały ograniczenia szarej strefy. Oceniały, że poprawi się dostęp do kredytów, a kontrahenci będą płacili swoje zobowiązania w terminie. Miały duże oczekiwania związane z dostępem do funduszy unijnych.

\section{Zakończenie}

Uzyskane wyniki finansowe w grupie małych i średnich przedsiębiorstw w latach 1994-2007 świadczą o znacznym rozwoju sektora MŚP w Polsce i zapełnianiu luki na rynku. Aktywność ekonomiczna tych podmiotów świadczy o wzrastającej roli indywidualnej przedsiębiorczości, zwiększeniu aktywności w różnych dziedzinach życia gospodarczego, lepszej stabilności działania. Obecnie warunki prowadzenia małego biznesu znacznie różnią się od tych, jakie występowały na początku okresu transformacji. Czas szybkich zysków powiązany z uzupełnianiem najłatwiejszych nisz rynkowych przeminął. Wzrost konkurencji spowodował, że małej firmie jest znacznie trudniej zarówno wejść na rynek, jak i utrzymać się na nim, pojawiła się bowiem niedostrzegana wcześniej bariera popytu i konkurencji.

Kondycja ekonomiczno-finansowa przedsiębiorstw małej i średniej skali jest stosunkowo dobra. Przychody tego sektora (obroty) w ciagu ostatnich lat systematycznie wzrastały. Udział kosztów w przychodach wykazywał względnie stały poziom, z zaznaczającą się w okresie tendencję wzrostową. Z analizy wskaźnikowej wynika, że sektor małych i średnich przedsiębiorstw osiaga dość dobre wyniki ekonomiczne. W badanym okresie znacznie wzrosła ekonomiczna efektywność sprzedaży. Podjęte w odpowiednim okresie właściwe decyzje organizacyjne przyniosły odpowiedni efekt finansowy firm, wyrażający się dodatnimi wartościami wskaźnika osiągniętych przychodów i poniesionych kosztów.

\footnotetext{
${ }^{1}$ Monitoring kondycji sektora MŚP, raport, Polska Konfederacja Pracodawców Polskich Lewiatan, Warszawa 2009, s. 45.
} 
Po przystąpieniu Polski do Unii Europejskiej małe przedsiębiorstwa krajów nowoprzyjętych stały się konkurencją dla państw Europy Zachodniej, zwłaszcza poprzez niskie ceny i dobrą jakość produktów. Z drugiej strony otwarcie rynków, zwłaszcza w tradycyjnych gałęziach produkcji, nałożyło nowe obciążenia na przedsiębiorstwa tego sektora i stworzyło nowe uwarunkowania. Unia Europejska wprowadziła instrumenty mające na celu usprawnienie zmian, a środki z dofinansowania unijnego pomogły zmniejszyć różnice między państwami przyjętymi a dotychczasowymi państwami członkowskimi, zwłaszcza przez fundusze strukturalne. Powstały specjalne programy i fundusze, które mają na celu promowanie przedsiębiorczości i podnoszenia kwalifikacji, polepszenie dostępu MŚP do rynków oraz zwiększenie potencjału wzrostu poprzez umożliwienie im rozwoju zdolności w zakresie badań i innowacji. Polskie małe i średnie przedsiębiorstwa wskazują aktywnie kierunki absolutnie niezbędnych działań, które powinny zostać podjęte przez rząd, aby przedsiębiorczość w Polsce mogła się rozwijać. Przedsiębiorcy podkreślają zbyt wysokie pozapłacowe koszty pracy, zbyt wysokie podatki od działalności gospodarczej, złożone procedury administracyjne, które podnoszą koszty działania przedsiębiorstw i ograniczają ich możliwości rozwoju. Ważną barierą jest brak możliwości stosowania elastycznych form zatrudnienia oraz stan infrastruktury.

\section{Literatura}

1. Alińska A., Latoszek E., 2008, Finansowanie MŚP w Polsce ze środków finansowych UE jako czynnik wpływajacy na konkurencyjność przedsiębiorstw, Oficyna Wydawnicza SGH, Warszawa.

2. Bednarczyk M. (red.), 2004, Mate i średnie przedsiębiorstwa w Polsce a integracja europejska, wyd. AE w Krakowie, Kraków.

3. Dominiak P., 2005, Sektor MŚP we współczesnej gospodarce, PWN, Warszawa.

4. Gołębiowski G., Tłaczała A., 2005, Analiza ekonomiczno-finansowa w ujęciu praktycznym, Warszawa.

5. Harmgardt W., Tiedtke J., 1992, Inwestycje i finansowanie, Die Akademie, Bad Harzburg.

6. Janiuk I., 2004, Strategiczne dostosowanie polskich matych i średnich przedsiębiorstw do konkurencji europejskiej, Warszawa.

7. Monitoring kondycji sektora MŚP, 2008, Polska Konfederacja Pracodawców Polskich Lewiatan, Warszawa.

8. Roszkowska S., 2004, Inwestycje a wzrost gospodarczy w krajach OECD, „Gospodarka Narodowa”, Instytut Rozwoju i Studiów Strategicznych nr 155/156-160, Warszawa.

9. Safin K. (red.), 2008, Zarzadzanie małym i średnim przedsiębiorstwem, Wyd. AE we Wrocławiu, Wrocław.

10. Strużycki M. (red. nauk.), 2004, Małe i średnie przedsiębiorstwa w gospodarce regionu, PWE, Warszawa.

11. Waniak-Michalak H., 2007, Pozabankowe źródła finansowania matych i średnich przedsiębiorstw, Wolters Kluwer Polska, Kraków.

12. Żołnierski A., Zadura P., Lichota R., 2008, Raport o stanie sektora MŚP w Polsce w latach 2006-2007, Polska Agencja Rozwoju Przedsiębiorczości, Warszawa. 


\section{Economic Activity of the SME Sector in Poland}

SME sector in the polish market economy and in another countries are growing rapidly last times. Small and medium-sized enterprises are a valuable resource for countries with developed market economy. They have importance role in the Polish economy and a great influence for their development. The development of this sector is related to the numerous circumstances like the development of national economy, economy structure and conditions, financial state and local governments as well economic policies. The researches in this area should know all the circumstances, to eliminate their negative impact and get propositions to economic policy, which allows eliminating these barriers.

The analysis of small and medium businesses, which will be presented in the article was carried out for the period 1994-2007. The analyses were based of statistical data obtained from CSO. Based on these data have been done analysis of small and medium businesses. In the article has shown the level of investment expenditures, economic and financial results MSP' sector in last years received positive indicator as the results of own activity. 